\title{
Investigation of the Relation Between FAS, FASLG Polymorphisms and Serum Fas, FasL Levels in Patients with Psoriasis
}

\author{
Gülay Gülbol Duran ${ }^{1 *}$, Mulkiye Kasap², Ramazan Gunesacar³ ${ }^{3}$ Asena Cigdem \\ Dogramac1 $^{4}$, Yasar Gul Denli ${ }^{5}$ \\ 1. Mustafa Kemal University, Medicine Faculty, Hatay, Turkey \\ 2. Cukurova University, Medicine Faculty, Department of Medical biology, Turkey \\ 3. Kahramanmaraş Sutcu Imam University, Medicine Faculty, Department of Medical Biology and \\ Genetic, Turkey \\ 4. Mustafa Kemal University, Medicine Faculty, Department of Dermatology, Turkey \\ 5. Çukurova University, Medicine Faculty, Department of Dermatology, Turkey
}

\begin{abstract}
Background: Psoriasis is a multifactorial and inflammatory chronic skin disease indicated with T-cell-mediated keratinocyte hyper-proliferation. Demographic, epidemiological (family, twin), serological, and genetic studies have clearly demonstrated that psoriasis is a polygenic and multifactorial disease.

Aim: The objectives of the study are; to determine the prevalence of the polymorphisms of FAS (Fas cell surface receptor gene) -671 A>G (rs:1800682) and FASLG (Fas ligand gene) -844 T>C (rs:763110), to investigate the serum levels of $S F$ as and $S F a s L$, and also to discover any relationship between gene polymorphisms and serum levels in psoriatic patients.

Material and Methods: 50 treated and 69 untreated patients, and 140 healthy controls were included in the study. Polymorphisms were determined using polymerase chain reaction-restriction fragment length polymorphism (PCR-RFLP) technique. The serum levels were measured in randomly selected treated (39) and untreated (40) patients, also in 84 healthy controls using micro-ELISA technique.

Results: There was no statistical difference between polymorphisms in the patient and control groups. However, sFas and sFasL levels in both treated and untreated patients were higher than that of the controls.

Conclusion: The investigated FAS and FASLG polymorphisms were not found to be directly associated with the psoriasis. Elevated sFas and SFasL levels in psoriatic patients showed that these factors may possess a significant role in the pathogenesis of psoriasis.
\end{abstract}

Keywords:FAS, FASLG, Psoriasis, PCR-RFLP

Received: $5^{\text {th }}$ March 2018; Accepted: 25 th June 2018; Published: $25^{\text {th }}$ June 2018

*Corresponding author: Gülay Gülbol Duran, Mustafa Kemal University, Medicine Faculty Hatay, Turkey. E-mail: gulayduran@gmail.com 


\section{Introduction}

Psoriasis is a multifactorial and inflammatory chronic skin disease indicated with T-cell-mediated keratinocyte hyper-proliferation. The disease typically appears with sharply demarcated erythematous plaques coated with silvery-white scales $(1,2)$. Psoriasis is considered to be an autoimmune disease, the most common T-cell-dependent inflammatory disease in humans, which is caused by a combination of genetic, environmental, and immunological factors (2). The etiopathogenesis of psoriasis is multifactorial due to the interaction between genetic and enviromental factors. The genetic factors influence the formation of the disease $(3,4)$. While psychiatric drugs, antigenic stimulation, and physical or emotional stress play an important role in triggering symptoms, most of the studies suggest that a strong genetic component causes disease susceptibility (5). It is thought that cytokines released from keratinocytes and inflammatory cells are involved in the triggering of psoriasis and the subsequent inflammatory process. It was thought that psoriasis only affects the skin. However, it has been suggested that inflammation is not limited by the definition of inflammatory arthritis in patients, and it is now claimed to be an immunological skin disease $(5,6)$.

Apoptosis is programmed cell death that plays a role in a number of physiological events such as providing hemostasis of tissue, controlling the number of cells, and elimination of unwanted cells in organism development $(7,8)$. It is also known to be involved in the pathogenesis of many inflammatory skin disorders. The Fas/ FasL signal is among the best known mechanism for induction of apoptosis, and it is a crucial early step during the psoriasis onset promoted by activated lymphocytes $(6,9)$. Fas-mediated apoptosis prevents the autoimmune reactions by removing the active T-cells from the medium resulting from the immunoreaction (10). In au- toimmune diseases, increases in defects and Fas levels were found in the Fas pathway $(11,12)$. The single nucleotide polymorphisms of the Fas cell surface receptor gene $(F A S)$ and the Fas ligand gene (FASLG), particularly in the promoter region, affect the expression of these genes, and thus their serum levels $(13,14)$. Soluble Fas (sFas) and soluble Fas ligand (sFasL) levels are important in patients with psoriasis, and there are reports that serum levels have changed due to treatment $(15,16)$. The polymorphisms of $F A S$ $-671 \mathrm{~A}>\mathrm{G}$ (rs: 1800682) and FASLG -844 $\mathrm{T}>\mathrm{C}$ (rs: 763110) are found in the promoter sites of FAS and FASLG genes and have been shown in a number of studies in which these polymorphisms are associated with numerous diseases (12,13,17-19). In our study, FAS -671 A $>\mathrm{G}$ (rs: 1800682) and FASLG -844 $\mathrm{T}>\mathrm{C}$ (rs: 763110) gene polymorphisms were preferred in order to investigate the relationship of these genes.

Specifically, we aimed to investigate whether FAS -671 A >G (rs: 1800682) and FASLG -844 $\mathrm{T}>\mathrm{C}$ (rs: 763110) polymorphisms were correlated with soluble Fas (sFas) and soluble FasL (sFasL) levels in Turkish psoriasis patients.

\section{Material and Methods}

One hundred and nineteen patients with psoriasis (65 female, 54 male; average age: 41.84; SD: 16.44) who were examined in the Dermatology Clinic of Mustafa Kemal University and Cukurova University and 140 healthy control subjects (76 female, 64 male; average age: 38.7; SD: 10.2) were included in the study. The study was approved by the Ethics Committee of the Medicine Faculty of Cukurova University. Patients who were diagnosed with psoriasis according to the clinical findings and observations of the dermatologists involved in this study were included. Patients who had an inflammatory skin disease other than psoriasis and who received systemic therapy for another reason 
were not included in the study. Healthy individuals with no family history of psoriasis and no relationship between them were selected for the control group. The first group of patients who received systemic treatment for psoriasis was referred to as the treatment group (50 patients). The second group of patients who received only topical treatment without systemic treatment for psoriasis was referred to as the untreated group (69 patients). All subjects included in the study received $2 \mathrm{ml}$ blood samples to EDTA tubes, and DNA isolation was performed by the standard method (20). For the micro-ELISA test, 5 $\mathrm{ml}$ blood samples were collected from the subjects into standard biochemical tubes, and they were allowed to clot for 1 hour and centrifuged at $1.000 \mathrm{~g}$. The obtained serum samples were divided into portions and were kept stored at -80 ${ }^{\circ} \mathrm{C}$ until used.

FAS -671 A $>\mathrm{G}$ and FASLG $-844 \mathrm{~T}>\mathrm{C}$ polymorphisms were analyzed with polymerase chain reaction-restriction fragment length polymorphism (PCR-RFLP) technique (21). Forward and reverse primers for FAS and FASLG were designed as follows, respectively: F:5-CTACCTAAGAGCTATCTACCGTTC-3', R:5-GGCTGTCCATGTGGCTGC-3'; and F:5-CAGCTACTCGGAGGCCAAG-3, R:5-GCTCTGAGGGGAGAGACCAT-3'. The total PCR volume was set at $25 \mu \mathrm{l}$ for FAS and FASLG optimal amplification. All components required for PCR reaction were purchased from Fermantas company. The PCR mixture was as follows: $\mathrm{MgCl}_{2}(50$ $\mathrm{mM}): 2 \mu \mathrm{l}$, each primer (10 pmol): $1 \mu \mathrm{l}$, dNTP mixture $(25 \mathrm{mM}): 0.2 \mu \mathrm{l}$, Taq Polymerase $(5 \mathrm{U} /$ $\mu \mathrm{l}$ ): $0.2 \mu \mathrm{l}$, PCR buffer (without $\mathrm{MgCl}_{2}$ ): $2.5 \mu \mathrm{l}$ and genomic DNA $(50 \mathrm{ng} / \mu \mathrm{l}): 1 \mu \mathrm{l}$. Cycling conditions for $F A S$ were set up as follows: $3 \mathrm{~min}$ at $94^{\circ} \mathrm{C}$ for the preliminary step, 40 cycles of; -1 min at $94^{\circ} \mathrm{C}$ for denaturation, $1 \mathrm{~min}$ at $62^{\circ} \mathrm{C}$ for annealing, and $1 \mathrm{~min}$ at $72^{\circ} \mathrm{C}$ for the extensionfollowed by $10 \mathrm{~min}$ at $72^{\circ} \mathrm{C}$ as a final extension using a thermal cycler (Flexigene-Techne). The
PCR product was displayed by gel electrophoresis at a length of 332 base pairs. Cycling conditions for FASLG were set up as follows: $2 \mathrm{~min}$ at $94^{\circ} \mathrm{C}$ for the preliminary step, 35 cycles of; -30 sec at $94^{\circ} \mathrm{C}$ for denaturation, $30 \mathrm{sec}$ at $62^{\circ} \mathrm{C}$ for annealing, and $45 \mathrm{sec}$ at $72^{\circ} \mathrm{C}$ for the extension - followed by $7 \mathrm{~min}$ at $72^{\circ} \mathrm{C}$ as a final extension using a thermal cycler (Flexigene-Techne). The PCR products were displayed with an agarose gel electrophoresis at a length of 401 base pairs.

The total volume was $25 \mu \mathrm{l}$ for digestion by the MvaI (Fermentas) restriction endonuclease of the FAS PCR product. The content of the reaction mixture was as follows: MvaI: $0.5 \mu \mathrm{l}$, PCR product: $5 \mu \mathrm{l}$, and PCR buffer: $2.5 \mu \mathrm{l}$. It was incubated overnight at $37^{\circ} \mathrm{C}$. The amplicons were run on $3 \%$ agarose gel (Sigma). The DNA fragments were monitored with a gel imaging system (Wealtec, Dolphin-View, ABD). Three different genotypes were detected as the following; AA: 233 and 99 bp, GG: 189, 99, and 44 bp, and AG: 233, 189, 99, and 44 bp fragments (Figure 1).

The total volume was set at $20 \mu \mathrm{l}$ for digest by the BseMI (Fermentas) restriction endonuclease of the FASLG PCR product. The content of the reaction mixture was as follows: BseMI: $0.5 \mu 1$, PCR product: $5 \mu 1$, and PCR buffer: 1.5

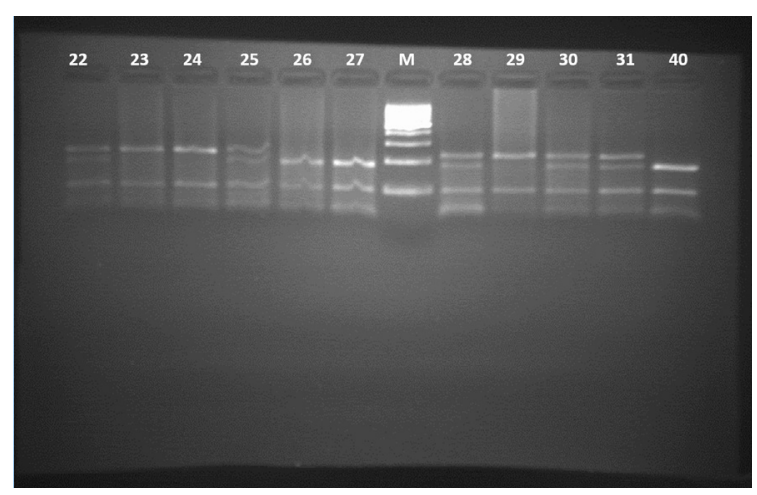

Fig. 1. Gel image of FAS $-671 \mathrm{~A}>\mathrm{G}$ polymorphism of patients with treated. [M: Marker (100bp). 22,25,28,30,31: AG genotype; 23,24,29: AA genotype; 26,27,40: GG 
$\mu 1$. It was incubated overnight at $55^{\circ} \mathrm{C}$. The amplicons were run on 3\% agarose gel. The DNA fragments were monitored as mentioned before. Three different genotypes were detected as the following; TT: $401 \mathrm{bp}, \mathrm{CC}: 233$ and $168 \mathrm{bp}$, and TC: 401, 233, and 168 bp fragments (Figure 2).

The serum levels of sFas and sFasL were analyzed using micro-ELISA kits (for sFas: RayBio Human Fas ELISA; for sFas: L eBioscience Platinum ELISA) according to manufacturer instructions.

\section{Statistical Analysis}

For our data, Kolmogorov Smirnov and Shapiro Wilk tests were used as normality tests. $\mathrm{p}>0.05$ was accepted as normal and parametric test was applied. Mann-Whitney U and Kruskal-Vallis tests were used to calculate the variables obtained by measurement. Mann-Whitney $U$ was used in two group comparisons, and an Kruskal-Vallis test was used in three group comparisons. A chi-square test was conducted to compare personal variables. The level of statistical significance was $\mathrm{p}=0.05$ in all tests, and a $p<0.05$ value was accepted as significant. The SPSS 13.0 package program was used for statistical analysis of the data.

\section{Results}

The genotype and allele frequencies were in Hardy-Weinberg equilibrium in both the pso-

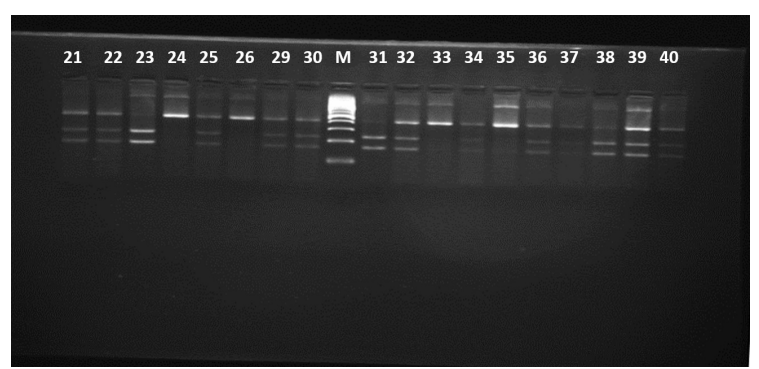

Fig. 2. Gel image of FASLG $-844 \mathrm{~T}>\mathrm{C}$ polymorphism of control group. [M: Marker (100bp). 21,22,25,29,30,32,34,36-40: TC genotype; 23,31: CC genotype; $24,26,33,35$ riasis patients and the healthy control subjects. The FAS $-671 \mathrm{~A}>\mathrm{G}$ genotype distribution and allele frequencies are listed in Table 1 . When we compared $F A S-671$ AG and GG genotypes and $\mathrm{G}$ allele frequencies between the psoriasis and control groups, no significant difference was found ( $A G, p=0.521 ; G G, p=0.726 ; G, p=0.929$ ). Serum sFas levels of patient and control groups were compared (Table 2), and we found that serum sFas levels were significantly higher in the patient group compared to the control group $(p<0.001)$. However the average $s F a s$ level in the treated group was $200.96 \mathrm{pg} / \mathrm{ml}$ whereas it was found to be $175.07 \mathrm{pg} / \mathrm{ml}$ in the untreated group. Serum sFas levels showed no significant difference between the treated group and the untreated group $(p=0.581)$. Serum levels of sFas, according to the three genotypes of all groups, are given in Table 3. In the control group, the sFas serum levels of AA genotypes were significantly higher than the other genotypes $(\mathrm{p}=0.001)$.

The FASLG -844 T>C genotype and allele frequencies are presented in Table 1 . There was no significant difference in the FASLG -844 TC and $\mathrm{CC}$ genotype frequencies, and the $\mathrm{C}$ allele frequencies between the psoriasis and control groups (TC, $\mathrm{p}=0.315 ; \mathrm{CC}, \mathrm{p}=0.332 ; \mathrm{C}, \mathrm{p}=0.792$ ). Serum sFasL levels were compared between the patient and control groups (Table 2). Serum sFasL levels in the patient group were significantly higher compared to the control group $(p<0.001)$. However the average $s F a s L$ level in the treated group was $0.44 \mathrm{ng} / \mathrm{ml}$ whereas it was found to be $0.53 \mathrm{ng} / \mathrm{ml}$ in the untreated group. Serum sFasL levels showed no significant difference between the treated group and the untreated group $(p=0.06)$. Serum levels of FasL were compared according to three genotypes (Table 3 ), and the difference in serum protein levels according to genotypes was not significant. Serum sFasL levels of all three genotypes were found to be similar in the control group as well as in the treated $(\mathrm{p}=0.753)$ and untreated groups $(\mathrm{p}=0.118)$. 
Table 1. Comparisons of genotype distribution and allele frequencies of the studied polymorphisms in patients with psoriasis and healthy controls

\begin{tabular}{|c|c|c|c|c|c|}
\hline Genotype/Allele & Psoriasis $(n=119)$ & Control $(n=140)$ & $X^{2}$ & OR $(95 \%$ CI $)$ & p value \\
\hline \multicolumn{6}{|l|}{$F A S-671 \mathrm{~A}>\mathrm{G}$} \\
\hline \multicolumn{6}{|c|}{ Genotype frequency } \\
\hline $\mathrm{AA}$ & $30(\% 25.21)$ & $31(\% 22.14)$ & 0.336 & $1,185(0.667-2.106)$ & Reference \\
\hline $\mathrm{AG}$ & $71(\% 59.66)$ & $90(\% 64.28)$ & 0.584 & $0.822(0.497-1.360)$ & 0.521 \\
\hline GG & $18(\% 15.13)$ & $19(\% 13.58)$ & 1.127 & $1.135(0.565-2.278)$ & 0.726 \\
\hline \multicolumn{6}{|l|}{ Allele frequency } \\
\hline A & $131(\% 55.04)$ & $152(\% 54.28)$ & 0.030 & $1.031(0.729-1.459)$ & Reference \\
\hline G & $107(\% 44.95)$ & $128(\% 54.72)$ & 0.030 & $0.970(0.685-1.372)$ & 0.929 \\
\hline \multicolumn{6}{|l|}{$F A S L G-844 \mathrm{~T}>\mathrm{C}$} \\
\hline \multicolumn{6}{|c|}{ Genotype frequency } \\
\hline TT & $15(\% 12.60)$ & $20(\% 14.28)$ & 0.155 & $0.865(0.422-1.776)$ & Reference \\
\hline $\mathrm{TC}$ & $93(\% 78.15)$ & $101(\% 72.15)$ & 1.235 & $1.281(0.781-2.444)$ & 0.315 \\
\hline $\mathrm{CC}$ & $11(\% 9.25)$ & $19(\% 13.57)$ & 1.176 & $0.649(0.295-1.424)$ & 0.332 \\
\hline \multicolumn{6}{|l|}{ Allele frequency } \\
\hline $\mathrm{T}$ & $123(\% 51.68)$ & $141(\% 50.36)$ & 0.090 & $1.054(0.746-1.490)$ & Reference \\
\hline $\mathrm{C}$ & $115(\% 48.32)$ & $139(\% 49.64)$ & 0.090 & $0.948(0.671-1.340)$ & 0.792 \\
\hline
\end{tabular}

\section{Discussion}

Psoriasis is a chronic inflammatory skin disease that is seen worldwide, leading to serious disorders in the quality of life (22).

The levels of anti-apoptotic and apoptotic factors regulate the initiation of apoptosis in the epidermis, and by means of that, epidermal growth and differentiation are regulated. Completion of keratinocyte differentiation is a simple and specific form of apoptosis (23). There are various mechanisms of apoptotic pathways in keratinocyte apoptosis. One of the most important of these pathways is the extrinsic pathway induced after binding of Fas ligand (FasL) or tumor necrosis factor (TNF) to transmembrane death receptors leading to caspase- 8 activation (24). In this study, we hypothesized that the signaling pathway of Fas/FasL may be impaired in the apoptotic process due to the hyperproliferation of keratinocytes. However, since poly- morphisms of the FAS and FASLG did not significantly differ between the patient and control groups, this finding was not clear. Nonetheless, the high levels of sFas and sFasL in patients indicate that this hypothesis may still apply.

In a study of systemic lupus erythematosus (SLE) patients in order to understand the role of the Fas/FasL system in autoimmune diseases,

\section{Table 2. Comparison of sFas and sFasL} levels of patient and control groups

\begin{tabular}{llcc}
\hline \multirow{2}{*}{ Groups } & & $\begin{array}{c}\text { sFas } \\
\text { ELISA } \\
(\mathbf{p g} / \mathbf{m l})\end{array}$ & $\begin{array}{c}\text { sFasL } \\
\text { ELISA } \\
(\mathbf{n g} / \mathbf{m l})\end{array}$ \\
\hline \multirow{2}{*}{$\begin{array}{l}\text { Psoriasis } \\
(\mathrm{n}=79)\end{array}$} & Median & 148.36 & 0.48 \\
\cline { 2 - 4 } & Minimum & 1.05 & 0.14 \\
\cline { 2 - 4 } $\begin{array}{l}\text { Control } \\
(\mathrm{n}=84)\end{array}$ & Maximum & 1031.06 & 1.06 \\
\cline { 2 - 4 } & Median & 83.47 & 0.36 \\
\cline { 2 - 4 } $\mathbf{p}$ value & Maximum & 1.05 & 0.14 \\
\hline
\end{tabular}


Table 3. Distribution of sFas and sFasL levels according to genotypes in treated, untreated, and control groups

\begin{tabular}{|c|c|c|c|c|c|c|c|c|c|c|}
\hline & \multirow[t]{2}{*}{ Genotypes } & \multicolumn{3}{|c|}{ Treated } & \multicolumn{3}{|c|}{ Untreated } & \multicolumn{3}{|c|}{ Control } \\
\hline & & $\mathbf{n}$ & Mean \pm SD & Median & $\mathbf{n}$ & Mean \pm SD & Median & $\mathbf{n}$ & Mean \pm SD & Median \\
\hline \multirow{4}{*}{ 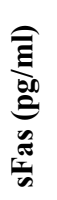 } & AA & 16 & $179.24 \pm 86.62$ & 179,24 & 4 & $116.57 \pm 38.68$ & 129,04 & 23 & $137.23 \pm 101.84$ & 116,77 \\
\hline & $\mathrm{AG}$ & 20 & $216.41 \pm 206.67$ & 154,46 & 28 & $179.82 \pm 119.60$ & 143,95 & 43 & $80.91 \pm 70.55$ & 76,04 \\
\hline & GG & 3 & $213.72 \pm 232.90$ & 96,62 & 8 & $187.67 \pm 114.94$ & 147,8 & 17 & $48.45 \pm 60.68$ & 83,47 \\
\hline & p value & & 0.768 & & & 0.558 & & & 0.001 & \\
\hline \multirow{4}{*}{ 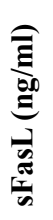 } & $\mathrm{TT}$ & 6 & $0.47 \pm 0.17$ & 0,4 & 7 & $0.52 \pm 0.17$ & 0,46 & 6 & $0.37 \pm 0.15$ & 0,38 \\
\hline & $\mathrm{TC}$ & 27 & $0.42 \pm 0.11$ & 0,44 & 29 & $0.52 \pm 0.13$ & 0,5 & 65 & $0.36 \pm 0.12$ & 0,36 \\
\hline & $\mathrm{CC}$ & 6 & $0.5 \pm 0.17$ & 0,5 & 4 & $0.64 \pm 0.09$ & 0,66 & 13 & $0.39 \pm 0.07$ & 0,38 \\
\hline & p value & & 0.753 & & & 0.118 & & & 0.391 & \\
\hline
\end{tabular}

when the levels of Fas and FasL proteins in SLE patients were found to be increased due to the severity of the disease, there was an inverse correlation between $\mathrm{sFas}$ levels and the stages of the disease (25). Also, in another study investigating the effects of $F A S$ and FASLG promoter region polymorphisms on serum levels in Guillain-Barré syndrome (GBS) patients, it was reported that promoter region SNPs raised serum levels and could be associated with the disease (26). In our study, we observed that sFas and sFasL levels significantly increased in patients compared to the control group $(\mathrm{p}<0.001)$, which was similar to the studies mentioned above. However, no significant difference was found between treated and untreated patients $[\mathrm{p}=0.581$ (Fas), $\mathrm{p}=0,06$ (FasL)].

There are several previous studies investigating the role of Fas/FasL on cell apoptosis in some autoimmune diseases and various tumors $(11,13,14,17,18,27,28)$. Furthermore, a recent study also showed that FASLG $-844 \mathrm{C} / \mathrm{T}$ polymorphism is associated with male infertility risk, suggesting that genetic variations in the Fas/FasL system may cause spermatogenesis defects (29). In our study, there was a significant increase in sFas and sFasL levels of psoriatic patients similar to the results of various cancer studies (30).
Uncontrolled proliferation in keratinocytes may be due to impaired apoptotic mechanisms mediated by Fas/FasL, or it may be due to an immune leak. It has been reported that sFasL levels are elevated in diseases with a maculopapular rash on the skin. FAS and FASLG polymorphisms cause increased risk of certain diseases $(12-14,17)$.

One of the surprising findings of our study is that sFas levels are high in the AA genotype individuals in the control group. Further work is needed in a wider population because the samples were taken from a small region and because our sample is of similar ethnic origin.

Also, whereas the basal expression is significantly increased in those with the $-844 \mathrm{C}$ allele in the FASLG compared to those with the $-844 \mathrm{~T}$ allele (14), in our study, the observed distribution of sFas and sFasL levels according to genotypes in treated, untreated, and control groups, showed no significant difference between sFasL levels of the CC genotype and sFasL levels of the other genotypes.

It has been reported that the $-844 \mathrm{CC}$ genotype increases sFasL levels and the FasL mediated signal in lymphocytes, and, in this case, it increases the risk of developing some autoimmune diseases (2). It has also been reported that this single nucleotide polymorphism leads 
to antigen-specific T-cell death, thereby increasing the cancer susceptibility of the patient (19). Unlike in the Sun et al. (2005) study, in our study, no significant correlation was found between the sFasL serum levels of the FASLG $-844 \mathrm{~T}>\mathrm{C}$ polymorphism $(\mathrm{p}>0.05)$. We found no significant difference between the TT, TC, and $\mathrm{CC}$ genotypes and the serum levels of sFasL in either the patient or the control group. However, regardless of genotypes, when the sFasL serum levels were compared between the patient group and the control group, the sFasL serum levels increased significantly in the patient group compared to the control group. We think that the expression of FAS and FASLG in psoriasis is different, but that this increase in expression is not due to FAS $-671 \mathrm{~A}>\mathrm{G}$ and FASLG $-844 \mathrm{~T}>\mathrm{C}$ polymorphisms. However, our results suggest that both FAS and FASLG may possess a crucial role in the pathogenesis of autoimmune diseases, like psoriasis. The fact that sFas and sFasL levels are close in treated and untreated patient groups, but levels of sFas and sFasL are higher in both groups of patients than in the control group suggests that further studies are needed in this regard. This significant increase in serum levels also suggests the possibility that the Fas/ FasL signalling pathway is disrupted.

There are limitations in the present study as the following;

Our study is representing a relatively small number of patients. Polymorphism studies mostly reflect the genotype profile of the population better when working with greater populations in size. Additionally, while all samples were used for genotyping experiments, a limited number of samples were used for serum level measurements. In our opinion, further studies with a larger population size are needed.

Psoriasis is a still unexplained disease. For this reason, applied therapies do not offer sufficient results. Recurrence of the disease even af- ter treatment can cause negative emotions and a lower quality of life in patients. Although it is known that the disease is triggered by environmental factors, genetic factors also clearly affect the disease. However, the lack of knowledge of genetic factors and the inability to detect a genetic defect specific to the disease prevents the development of therapy methods.

\section{Conclusion}

In this study, we investigated whether $F A S$ and FASLG polymorphisms were effective in psoriasis. For this purpose, we analized any correlation between the serum levels of soluble Fas and FasL and the polymorphisms. We found that the polymorphisms we looked for did not affect serum levels. However, we think that we focussed on the right genes because the serum levels in the patient group were significantly higher than the ones in the control group. Therefore, other polymorphisms in these genes should also be examined. We also believe that genetic studies will have an important role to enlighten the immunopathogenesis of psoriasis. For this reason, future genetic work will be very important in understanding the genetic basis of the disease.

\section{Abbreviations}

FAS: Fas Cell Surface Receptor Gene; FASLG: Fas Ligand Gene; sFas: Soluble Fas; sFasL: Soluble Fas Ligand; PCR-RFLP: Polymerase Chain Reaction-Restriction Fragment Length Polymorphism

\section{Acknowledgments}

This research was financed by Çukurova University Scientific Research Projects Unit (Project Number: TF2010D13), Adana, Turkey. This study has been in accordance with both legal and ethical grounds. 


\section{Authors' Contribution}

GGD worked on plannig and all phase of study, laboratory studies; MK and RG consulted and executed the study; ACD and YGD collected the clinical specimens.

\section{References}

1. Langley RG, Krueger GG, Griffiths CE. Psoriasis: epidemiology, clinical features, and quality of life. Ann Rheum Dis. 2005;64 Suppl 2: ii18-ii23. DOI: 10.1136/ ard.2004.033217

2. Erkek E. Psoriazis Etyopatogenezi. Turkiye Klinikleri J Dermatol-Special Topics. 2008;1(3):1-14.

3. Roman II, Orasan MS, Coneac A, Marina EM, Pop AD, Orasan RI. Genetic and Hormonal Determinations in a Pair of Identical Twins with Early Onset Psoriasis Vulgaris: Case Report and a Brief Review of the Literature. Rev Romana Med Lab. 2017; 25(3):287-94 DOI: 10.1515/rrlm-2017-0021

4. Oskay T, Erdem C. Apopitoz ve Dermatolojideki Önemi. Turkiye Klinikleri J Dermatol. 2000;10(3):21321.

5. Ada S. Psoriazis Sistemik Bir Hastalık mıdır? Turkiye Klinikleri J Dermatol-Special Topics. 2008;1(3):45-8.

6. Oskay T, KundakçI N. Psoriasisde genetik bulgular. Turkiye Klinikleri J Dermatol. 2000;10(2):139-45.

7. Asgari R, Yari K, Mansouri K, Bakhtiari M. Association analysis of FAS $-670 \mathrm{~A} / \mathrm{G}$ and FASL $-844 \mathrm{C} / \mathrm{T}$ polymorphisms with risk of generalized agressive periodontitis disease. Biomed Rep. 2018;8 (4): 391-395.

8. Ozdemirkiran FG, Nalbantoglu S, Gokgoz Z, Payzin BK, Vural F, Cagiran S, Berdeli A. FAS/FASL gene polymorphisms in Turkish patients with chronic myeloproliferative disorders. Arch Med Sci. 2017;13(2): 426-432. DOI: 10.5114/aoms.2015.53963

9. Gilhar A, Yaniv R, Assy B, Serafimovich S, Ullmann Y, Kalish RS. Fas pulls the trigger on psoriasis. Am J Pathol. 2006;168(1):170-5. DOI: 10.2353/ajpath.2006.041354

10. Ashkenazi A, Dixit VM. Death receptors: signaling and modulation. Science. 1998;281(5381):1305-8. DOI: $10.1126 /$ science. 281.5381 .1305

11. Fisher GH, Rosenberg FJ, Straus SE, Dale JK, Middleton LA, Lin AY, et al. Dominant interfering Fas gene mutations impair apoptosis in a human autoimmune lymphoproliferative syndrome. Cell. 1995;81(6):93546. DOI: 10.1016/0092-8674(95)90013-6

12. Huang QR, Morris D, Manolios N. Identification and characterization of polymorphisms in the promoter region of the human Apo-1/Fas (CD95) gene. Mol Immunol. 1997;34(8-9):577-82. DOI: 10.1016/S01615890(97)00081-3
13. Kanemitsu S, Ihara K, Saifddin A, Otsuka T, Takeuchi $\mathrm{T}$, Nagayama J, et al. A functional polymorphism in fas (CD95/APO-1) gene promoter associated with systemic lupus erythematosus. J Rheumatol. 2002;29(6):11838.

14. Wu J, Metz C, Xu X, Abe R, Gibson AW, Edberg JC, et al. A novel polymorphic CAAT/enhancer-binding protein beta element in the FasL gene promoter alters Fas ligand expression: a candidate background gene in African American systemic lupus erythematosus patients. J Immunol. 2003;170(1):132-8. DOI: 10.4049/jimmunol.170.1.132

15. Seishima M, Seishima M, Takemura M, Saito K, Kitajima Y. Increased serum soluble Fas, tumor necrosis factor alpha and interleukin 6 concentrations in generalized pustular psoriasis. Dermatology. 1998;196(3):3712.

16. Mysliwiec H, Baran A, Mysliwiec P, Gorska M, Flisiak I. Upregulation of the sFas/sFasL system in psoriatic patients. Add Med Sci. 2015;60(1):64-8. DOI: 10.1016/j.advms.2014.10.005

17. Sibley K, Rollinson S, Allan JM, Smith AG, Law GR, Roddam PL, et al. Functional FAS promoter polymorphisms are associated with increased risk of acute myeloid leukemia. Cancer Res. 2003;63(15):4327-30.

18. Xia B, Yu YH, Guo QS, Li XY, Jiang L, Li J. Association of Fas-670 gene polymorphism with inflammatory bowel disease in Chinese patients. World J Gastroenterol. 2005;11(3):415-7. DOI: 10.3748/wjg.v11.i3.415

19. Sun T, Zhou Y, Li H, Han X, Shi Y, Wang L, et al. FASL-844C polymorphism is associated with increased activation-induced $\mathrm{T}$ cell death and risk of cervical cancer. J Exp Med. 2005;202(7):967-74. DOI: 10.1084/jem.20050707

20. Miller SA, Dykes DD, Polesky HF. A simple salting out procedure for extracting DNA from human nucleated cells. Nucleic Acids Res. 1988;16(3):1215. DOI: 10.1093/nar/16.3.1215

21. Ozel EG, Duran GG, Celik MM, Duran N, Gunesacar R. Fas and Fas ligand gene polymophisims in Turkish patient with Familial Mediterranean Fever. Gene. 2017; 623:29-32. DOI: 10.1016/j.gene.2017.04.037

22. Ghoreschi K, Mrowietz U, Röcken M. A molecule solves psoriasis? Systemic therapies for psoriasis inducing interleukin 4 and Th2 responses. J Mol Med. 2003;81(8):471-80. DOI: 10.1007/s00109-003-0460-9

23. Allombert-Blaise C, Tamiji S, Mortier L, Fauvel H, Tual M, Delaporte E, et al. Terminal differentiation of human epidermal keratinocytes involves mitochondria- and caspase-dependent cell death pathway. Cell Death Differ. 2003;10(7):850-2. DOI: 10.1038/ sj.cdd. 4401245

24. Curtin JF, Cotter TG. Live and let die: regulatory mechanisms in Fas-mediated apoptosis. Cell Signal. 2003;15(11):983-92. DOI: $10.1016 /$ S0898- 
6568(03)00093-7

25. Alenzi FQ. The role of apoptotic proteins in patients with systemic lupus erythematosis. Egypt $\mathrm{J}$ Immunol. 2009;16(1):107-16.

26. Islam Z, Jahan I, Ahammad RU, Shahnaij M, Nahar S, Mohammad QD. FAS promoter polymorphisms and serum sFas level are associated with increased risk of nerve damage in Banladeshi patients with Guillain-Barre syndrome. Plos One. 2018;12;13(2): e0192703.

27. Leithäuser F, Dhein J, Mechtersheimer G, Koretz $\mathrm{K}$, Brüderlein S, Henne C, et al. Constitutive and induced expression of APO-1, a new member of the nerve growth factor/tumor necrosis factor receptor superfamily, in normal and neoplastic cells. Lab Invest. 1993;69(4):415-29.
28. Kim K-M, Lee K, Hong Y-S, Park H-Y. Fas-mediated apoptosis and expression of related genes in human malignant hematopoietic cells. Exp Mol Med. 2000;32(4):246. DOI: 10.1038/emm.2000.41

29. Asgari R, Mansouri K, Bakhtiari M, Bidmeshkipour A, Yari K, Zadeh FS, Raygani AV. Association of FAS $-670 \mathrm{~A} / \mathrm{G}$ and FASL $-844 \mathrm{C} / \mathrm{T}$ polymorphisms with idiopathic azospermia in Wertern Iran. Eur J Obstet Gynecol Reprod Biol. 2017; 218: 55-59. DOI: 10.1016/j. ejogrb.2017.09.003

30. Park JY, Lee W-K, Jung D-K, Choi J-E, Park T-I, Lee E-B, et al. Polymorphisms in the FAS and FASL Genes and Survival of Early Stage Non-small Cell Lung Cancer. Clin Cancer Res. 2009;15(5):1794-800. DOI: 10.1158/1078-0432.CCR-08-1770 